\title{
FUKOSANTIN: KAROTENOID BERHARGA DARI MAKROALGA COKLAT
}

\section{Oleh}

\author{
Tri Handayani)
}

\section{ABSTRACT}

\section{FUCOXANTHIN: A HIGH VALUE CAROTENOID FROM BROWN} MACROALGAE. Fucoxanthin is carotenoid that can be found in marine brown seaweed (macroalgae) and diatoms (microalgae). Fucoxanthin has been isolated from brown macroalgae for its bioactivities study, including: Cystoceira barbata, Sargassum aquifolium, Sargassum filipendula, Sargassum ilicifolium, Sargassum wightii, Alaria crassifolia, Cladosiphon okamuranus, Cystoseira hakodatensis, Eisenia bicyclis,

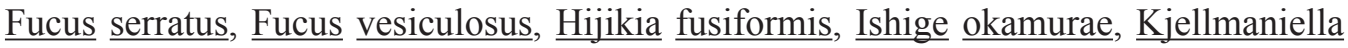

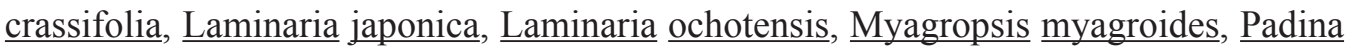
tetrastromatica, Petalonia binghamiae, Sargassum fulvellum, Sargassum heterophyllum,

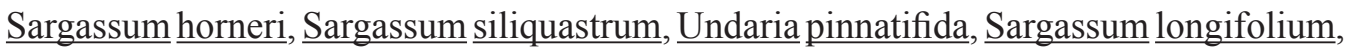
Padina sp, Turbinaria sp, and Undaria pinnatifida. The amount of fucoxanthin depends on the species of algae. Fucoxanthin has been reported to have bioactivities, i.e. antioxidant, antiinflammatory, anticancer, antiobese, antidiabetic, antiangiogenic, and pigmentation inhibitory.

\section{PENDAHULUAN}

Laut menyimpan banyak sumber daya yang dapat kita manfaatkan bagi kehidupan manusia. Sumber daya laut tersebut dapat berupa mineral, minyak bumi, perikanan, biota laut lainnya dan pariwisata. Adapun pemanfaatannya antara lain dapat digunakan sebagai sumber energi, pangan, pakan dan farmasi. Pemanfaatan sumber daya laut dalam bidang farmasi (bahan bioaktif), saat ini sedang hangat dibahas di bidang industri. Banyak industri farmasi yang memanfaatkan bahan baku dari biota laut untuk diambil bahan bioaktifnya, salah satunya adalah bahan bioaktif yang

\footnotetext{
1) Pusat Penelitian Oseanografi, LIPI
}

berasal dari makroalga.

Makroalga merupakan salah satu biota laut yang sudah sejak lama dimanfaatkan oleh industri farmasi. Fukosantin merupakan salah satu bahan bioaktif dari makroalga yang dimanfaatkan untuk industri farmasi. Fukosantin merupakan salah satu karotenoid yang hanya dihasilkan oleh makroalga coklat dan diatom (mikroalga). Bahan bioaktif ini hanya dihasilkan oleh makroalga coklat dan diatom saja, sehingga jumlah ketersediaan dengan jumlah permintaan fukosantin tidak seimbang. Kondisi ini menjadi fokus yang harus diperhatikan dan membutuhkan 
penyelesaian. Fukosantin sudah banyak dimanfaatkan di industri farmasi, namun belum banyak yang tahu tentang bagaimana karakteristik fukosantin, dan pemanfaatannya secara spesifik di bidang farmasi.

Tulisan ini membahas secara singkatmengenaikarakteristik fukosantin, makroalga penghasil fukosantin, peranan fukosantin sebagai bahan bioaktif yang dimanfaatkan untuk kepentingan farmasi, serta bagaimana proses fukosantin dapat memberikan efek secara farmakologi.

\section{KARAKTERISTIK FUKOSANTIN}

Fukosantin merupakan pigmen warna oranye atau karotenoid terbesar dari makroalga coklat. Pigmen ini terbentuk bersama-sama dengan klorofil a, klorofil b dan $\beta$-karoten yang dihasilkan oleh makroalga coklat dari Divisi Ochrophyta (Kanazawa et al., 2008; Peng et al., 2011). Fukosantin memiliki sifat biologis yang luar biasa berdasarkan sifat molekulnya yang unik seperti neosantin, dinosantin dan peridinin (Kanazawa et al., 2008). Fukosantin memiliki ikatan alenik yang tidak biasa dan beberapa kelompok aksigenik fungsional epoksi, hidroksil, karbonil, dan karboksil di dalam molekulnya. Struktur fukosantin dijelaskan pada Gambar 1.

Fukosantin pertama kali diisolasi dari makroalga coklat Fucus,
Dictyota dan Laminaria pada tahun 1914 (Wilstatter \& Page dalam Peng et al., 2011). Beberapa jenis makroalga telah diisolasi fukosantinnya sebagai senyawa yang memiliki bioaktivitas terhadap kesehatan, antara lain: Cystoceira barbata (Ryabushko et al., 2014), Sargassum aquifolium (S. binderi) (Noviendri et al., 2011), Sargassum filipendula (Zailanie \& Purnomo, 2017), Sargassum ilicifolium (S. duplicatum) (Noviendri et al., 2011; Sudhakar et al., 2013)., Sargassum wightii, Sargassum longifolium, Padina sp. Turbinaria sp. (Sudhakar et al., 2013), Undaria pinnatifida (Kanda et al., 2014), Alaria crassifolia (Arianthi et al., 2011), Cladosiphon okamuranus (Mise et al., 2011), Cystoseira hakodatensis, Eisenia bicyclis (Arianthi et al., 2011), Fucus serratus, Fucus vesiculosus (Zagaroza et al., 2008), Hijikia fusiformis (Yan et al., 1999), Ishige okamurae (Kim et al., 2010a), Kjellmaniella crassifolia (Arianthi et al., 2011), Laminaria japonica, Laminaria ochotensis (Miyata et al., 2009) Myagropsis myagroides (Heo et al., 2010), Padina tetrastromatica (Sangeetha et al., 2010), Petalonia binghamiae (Murakami et al., 2002), Sargassum siliquastrum (Heo et al., 2008), Sargassum heterophyllum (Afolayan et al., 2008), dan Undaria pinnatifida (Kanda et al., 2014). Makroalga coklat memiliki kandungan fukosantin yang berbeda-beda kadarnya tergantung jenisnya (Tabel 1). 


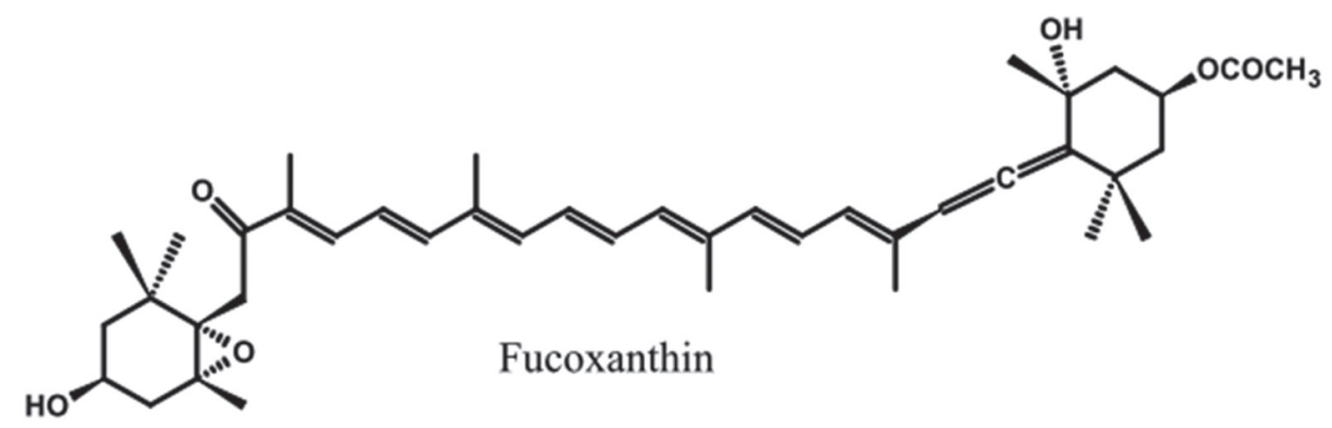

Gambar 1. Struktur fukosantin (Peng et al., 2011).

Tabel 1. Kandungan fukosantin dari makroalga coklat.

\begin{tabular}{|l|l|c|l|}
\hline No & \multicolumn{1}{|c|}{ Nama Spesies } & $\begin{array}{c}\text { Kandungan } \\
\text { Fukosantin (mg/g) }\end{array}$ & \multicolumn{1}{c|}{ Sumber } \\
\hline 1 & Cystoceira barbata & 1,34 & Ryabushko et al. $(2014)$ \\
\hline 2 & $\begin{array}{l}\text { Sargassum aquifolium }(S . \\
\text { binderi) }\end{array}$ & 1,01 & Noviendri et al. (2011) \\
\hline 3 & Sargassum filipendula & 1,08 & Zailanie \& Purnomo (2017) \\
\hline 4 & $\begin{array}{l}\text { Sargassum ilicifolium (S. } \\
\text { duplicatum) }\end{array}$ & $0,23-0,73$ & $\begin{array}{l}\text { Noviendri et al. (2011); } \\
\text { Sudhakar } \text { et al. }(2013) .\end{array}$ \\
\hline 5 & Sargassum wightii & 0,12 & Sudhakar et al. (2013). \\
\hline 6 & Sargassum longifolium & 0,09 & Sudhakar et al. (2013). \\
\hline 7 & Padina sp. & 0,23 & Sudhakar et al. $(2013)$. \\
\hline 8 & Turbinaria sp & 0,23 & Sudhakar et al. (2013). \\
\hline 9 & Undaria pinnatifida & 0,39 & Kanda et al. (2014) \\
\hline
\end{tabular}

\section{POTENSI FUKOSANTIN}

Fukosantin merupakan senyawa bioaktif yang banyak dimanfaatkan dalam dunia farmasi. Fukosantin memiliki kemampuan/aktivitas antara lain sebagai berikut:

\section{a. Aktivitas antioksidan}

Aktivitas antioksidan merupakan karakteristik penting dari karotenoid, begitu pula dengan fukosantin yang merupakan karotenoid dari makroalga coklat. Fukosantin juga mengumpulkan radikal yang efektif. Radikal yang dihasilkan secara kimiawi digunakan untuk mengevaluasi aktivitas antioksidan fukosantin, antara lain: DPPH (1,1-diphenyl-2picrylhydrazyl), 12-DS (12-doxylstearic acid), NB-L (the radical adduct of nitrosobenzene with linolenic acid radical), AAPH (2,2'-azo-bis-(2amidinopropane) dihydrochloride), ABTS (2,2'-azinobis-3ethylbenzothiazoline-6-sulphonate), dan ABAP (2,2'-azo-bis-2amidinopropane) (Sachindra et al., 
2007; Zaragosa et al., 2008; Arianthi et al., 2011).

Cladosiphon merupakan contoh marga makroalga yang memiliki aktivitas antioksidan. Ekstrak C. okamuranus menunjukkan aktivitas radikal DPPH yang kuat (Mise et al., 2011). Ekstrak metanol C. hakodatensis adalah sumber yang baik untuk anti oksidan, dan tingginya aktivitas antioksidan tidak hanya disebabkan kandungan fenolat yang tinggi, tetapi juga pada keberadaan fukosantin, yang menunjukkan sinergi dalam aktivitas antioksidan fenolik dan fukosantin (Arianthi et al., 2011).

Aktivitas antioksidan fukosantin dan dua metabolitnya (fukosantinol dan halocynthiaxanthin) berhubungan dengan pengikatan radikal (DPPH, ABTS, radikal hidroksil, dan radikal superoksida). Fukosantinol menunjukkan aktivitas antioksidan yang lebih tinggi atau setara dengan $\alpha$-tocoferol, sedangkan halocynthiaxanthin menunjukkan aktivitas antioksidan yang lebih rendah (Sachindra et al., 2007).

Penelitian yang membandingkan efek fukosantin dan $\beta$-karoten pada indikator stres oksidatif (katalase, glutathione transferase, dan $\mathrm{Na}^{+}$ $\mathrm{K}^{+}$-ATPase), dan peranan fukosantin dalam menekan peroksidasi lipid pada tikus yang mengalami defisiensi retinol. Hasil penelitian menunjukkan bahwa fukosantin dan $\beta$-karoten dapat melindungi membran sel dari penurunan aktivitas $\mathrm{Na}^{+} \mathrm{K}^{+}-$ ATPase. Selain itu, fukosantin dapat meningkatkan aktivitas katalase dan glutathione transferase pada jaringan dan mikrosom. Hasil penelitian tersebut semakin memperkuat dugaan bahwa fukosantin dan $\beta$-karoten memiliki aktivitas antioksidan dengan cara melindungi membran terhadap peroksidasi lipid yang disebabkan oleh defisiensi retinol. Hasil penelitian juga menunjukkan bahwa fukosantin memiliki potensi lebih besar daripada $\beta$-karoten dan lebih efektif daripada retinol dalam mengurangi peroksidasi lipid dalam plasma dan hati yang dihasilkan dari defisiensi retinol (Sangeetha et al., 2008;2009).

\section{b. Aktivitas antikanker}

Penelitian aktivitas antikanker dari fukosantin telah banyak dilakukan. Fukosantin menunjukkan aktivitas antiproliferatif yang kuat dan dapat menginduksi apoptosis/ kematian sel HL-60 (human leukemia). Dalam sel-sel HL-60, fukosantin menyebabkan pembelahan procaspase-3 dan poly-ADP-ribose polymerase. Induksi apoptosis oleh fukosantin dimediasi melalui permeabilisasi membran mitokondria dan caspase-9 dan aktivasi caspase-3 (Hosokawa et al., 1999; Kotake-Nara et al., 2005).

Fukosantin menginduksi pembentukan oksigen reaktif, menonaktifkan laju persinyalan Bcl-xL, menginduksi caspase-3,-7, dan poly-ADP-ribose polimerase, 
serta memicu apoptosis sel-sel HL60. Kondisi tersebut menunjukkan bahwa pembentukan oksigen reaktif adalah target penting dalam apoptosis sel-sel HL-60 yang diinduksi oleh fukosantin (Kim et al., 2010a).

Fukosantin, astasantin, siponasantin, neosantin, dan violasantin memiliki efek sitotoksik yang signifikan terhadap kultur sel HL-60. Aktivitas penghambatan fukosantin pada viabilitas sel-sel HL60 lebih baik dibandingkan dengan astasantin, $\beta$-karoten, zeasantin, dan lutein. Halocynthiaxanthin dan fucoxanthinol menunjukkan induksi yang lebih baik terhadap apoptosis sel-sel HL-60, sel-sel kanker payudara MCF-7, selsel kanker usus Caco-2, dan efek antiproliferatif. Halocynthiaxanthin dan fucoxanthinol lebih baik dalam menginduksi apotopsis pada sel-sel tersebut daripada fukosantin (Konishi et al., 2006; Ganesan et al., 2011). 5,6-epoksida dalam fukosantin dan fucoxanthinol berperan penting dalam sitotoksisitas dan mekanisme antiproliferatif epoxycarotenoid pada sel PC-3 (Asai et al., 2004).

Peranan fukosantin lainnya adalah sebagai penghambat pertumbuhan sel hepatocellular carcinoma (HepG2) pada manusia (Satomi \& Nishino, 2007). Fukosantin secara efektif menghambat proliferasi sel hepatoma SK-Hep-1 pada manusia, tetapi memfasilitasi pertumbuhan sel murine embrionik hepatic BNL CL.2. Fukosantin secara signifikan meningkatkan protein dan ekspresi mRNA dari connexin 43 dan connexin 32 pada sel SK-Hep-1, sehingga meningkatkan perbedaan interseluler antar sel SK-Hep-1. Fukosantin juga meningkatkan kadar kalsium intraseluler yang memengaruhi siklus sel pada fase G0 / G1, fragmentasi DNA, dan apoptosis Sel SK-Hep-1 (Liu et al., 2009).

Fukosantin menghambat pertumbuhan sel neuroblastoma pada manusia dengan menghambat fase G0-G1 dari siklus sel, dan menurunkan ekspresi gen N-myc. Aktivitas anti kanker dari fukosantin secara umum didasarkan pada efek regulatif dari fukosantin terhadap biomolekul yang berkaitan dengan siklus sel dan apoptosis (Miyashita et al., 2011). Selain itu, fukosantin secara selektif menghambat aktivitas DNA polymerase mamalia, khususnya replikasi DNA polimerase (yaitu: pol $\alpha, \delta$, dan $\varepsilon$ ), dan memiliki aktivitas anti neoplastik (Murakami et al., 2002)

\section{c. Aktivitas antiobesitas}

Akumulasi lemak yang berlebihan di dalam tubuh dan jaringan adiposa putih (white adipose tissue) menyebabkan obesitas dan gangguan sekresi sitokin dari jaringan adiposa pada manusia (Peng et al., 2011). Percobaan yang dilakukan oleh Maeda et al. (2005) menunjukkan bahwa fukosantin memiliki aktivitas dalam menurunkan berat badan pada mencit. Penelitian tersebut dilakukan 
pada mencit dengan membandingkan antara yang diberi pakan yang mengandung fukosantin, glikolipid dan kontrol. Hasil penelitian menunjukkan bahwa penggunaan pakan yang mengandung fukosantin dapat menurunkan berat WAT (white adipose tissues) mencit (Gambar 2).

Fukosantin menjadi satusatunya makanan konstituen di dunia yang menyebabkan ekspresi UCP1 (uncoupling protein 1) pada jaringan WAT. Fukoxanthin sekarang diharapkan dapat menjadi suplemen makanan dengan efek sindrom antimetabolik (Maeda et al., 2005).

Fukosantin secara signifikan mengurangi konsentrasi trigliserida plasma dan hati; menurunkan aktivitas sintesis asam lemak adipositik, sintesis asam lemak dan trigliserida hati, serta enzim pengatur kolesterol. Selain itu, fukosantin secara signifikan meningkatkan konsentrasi lipoprotein-kolesterol plasma, trigliserida dan kolesterol feces, serta aktivitas enzim oksidasi asam lemak dalam jaringan adiposa putih pada epididimis tikus. Fukosantin dapat memperbaiki profil lipid plasma, lipid hati, lipid tinja, massa lemak tubuh, metabolisme kolesterol hati, sintesis asam lemak, dan penyerapan lemak (Jeon et al., 2010; Woo et al., 2010). Selain itu, fukosantin secara signifikan menurunkan ekspresi mRNA dan aktivitas fosfat fosfohidrolase pada hati (Woo et al., 2010).

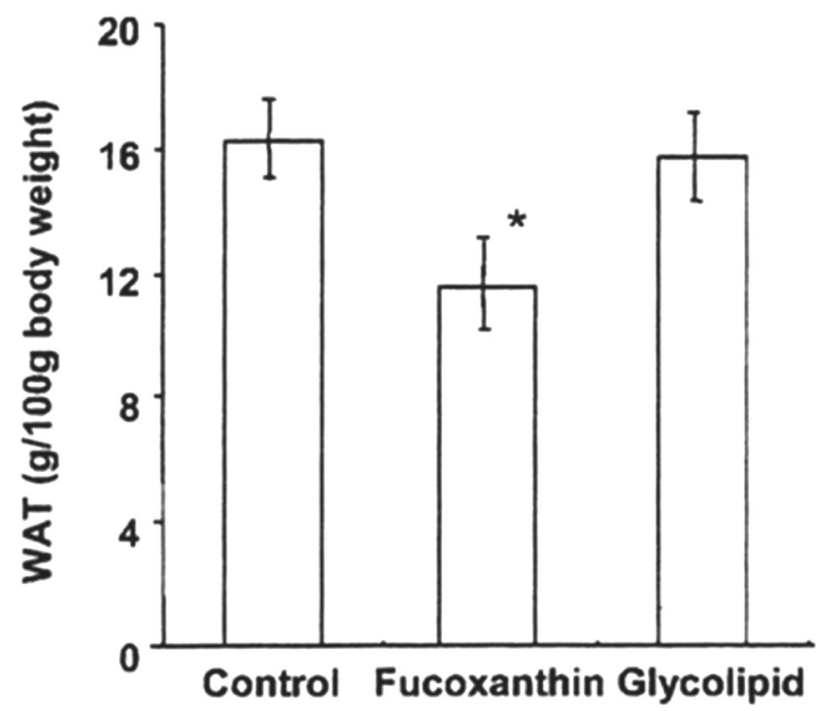

Gambar 2. Penghambatan/penurunan berat WAT pada mencit yang diberi pakan yang mengandung fukosantin pada $\mathrm{P}<0,01$ (Maeda et al., 2005). 


\section{d. Efek anti inflamasi}

Fukosantin memiliki efek menghambat inflamasi sitokin dan mediator pada makrofag RAW 264.7 yang dirangsang oleh lipopolisakarida. Fukosantin menghambat induksi nitric oxide synthase dan ekspresi cyclooxygenase 2. Fukosantin juga mengurangi tingkat oksida nitrat, prostaglandin E2, tumor necrosis factor- $\alpha$, interleukin-1 $\beta$, dan interleukin-6 melalui penghambatan aktivasi faktor-kB nuklir dan fosforilasi kinase protein yang diaktifkan mitogen (Heo et al., 2008; Kim et al., 2010b). Selain itu, fukosantin secara signifikan menghambat pembengkakan dan mengurangi tingkat tumor necrosis faktor- $\alpha$ dan histamin. Hal ini menunjukkan bahwa fukosantin memberikan efek antiinflamasi dengan menekan degranulasi sel mast secara in vivo (Sakai et al., 2011).

\section{e. Aktivitas antidiabetes}

Fukosantin merupakan senyawa yang memiliki aktivitas anti diabetes. Penambahan fukosantin (dengan kemurnian 97\%) pada pakan mencit sebanyak $1 \%$ dan $2 \%$ selama 4 minggu, menunjukkan hasil bahwa terjadi penurunan konsentrasi glukosa darah, kadar insulin serum dan konsentrasi leptin serum dibandingkan dengan perlakuan kontrol (Gambar 3). Ketika leptin disekresikan dari jaringan adiposa, aktivitas fukosantin untuk menurunkan konsentrasi serum leptin diyakini dilakukan dengan mengurangi jaringan adiposa putih (WAT). Dengan demikian fukosantin diharapkan dapat mengurangi kadar glukosa darah yang tinggi yang disebabkan oleh akumulasi lemak visceral (obesitas) (Maeda et al., 2007)

Penelitian peran fukosantin sebagai antidiabetes memberikan hasil yang bervariasi, dipengaruhi oleh antara lain konsentrasi fukosantin, hewan uji, dan durasi perlakuan uji. Fukosantin melemahkan hiperglikemia pada mencit, tetapi tidak memengaruhi kadar glukosa darah pada mencit (Hokosawa et al., 2010). Fukosantin dari Undaria pinnatifida dapat menurunkan konsentrasi glukosa darah, kadar insulin plasma, dan indeks resistensi insulin pada tikus obesitas yang diinduksi melalui diet/ pola makan. Fukosantin memiliki indikasi dalam meningkatkan perubahan metabolisme lipid dan resistensi insulin yang diinduksi oleh diet lemak tinggi, melalui pengurangan berat lemak visceral, hiperinsulinemia, produksi glukosa hati, dan lipogenesis hati. Fukosantin juga mengubah aktivitas enzim pengatur glukosa hati (Park et al., 2011).

Fukosantin secara signifikan mengurangi glukosa darah, hemoglobin A1c, insulin plasma, dan kadar resistin. Tidak ditemukannya perubahan dalam konsentrasi glukagon plasma dalam diet tinggi lemak yang diberikan pada tikus, menunjukkan bahwa pengurangan rasio insulin / glukagon bisa menjadi bagian yang bertanggung jawab untuk menurunkan konsentrasi glukosa darah oleh fukosantin (Woo et al., 2010). 

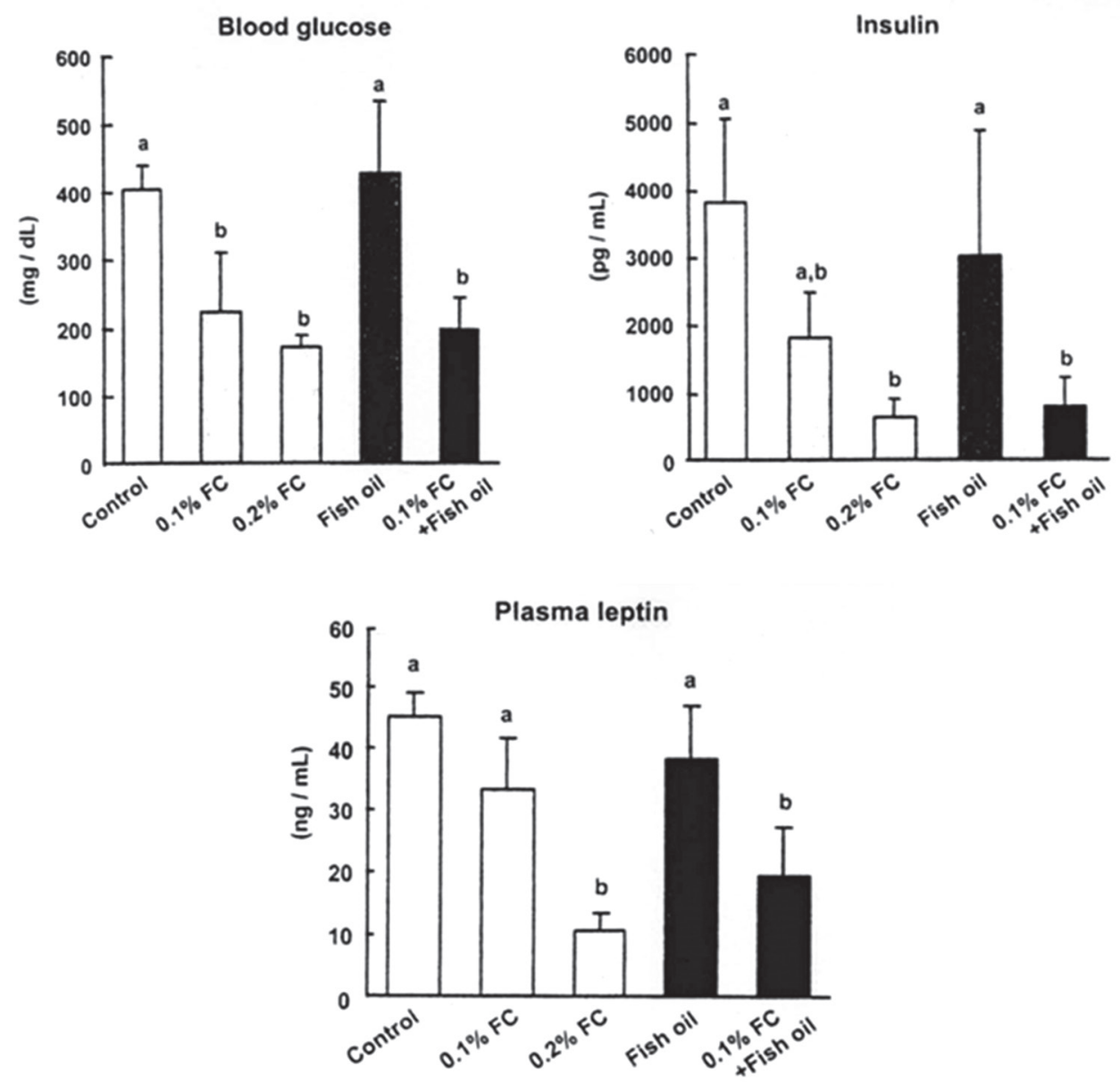

Gambar 3. Penurunan konsentrasi glukosa darah, kadar insulin serum dan konsentrasi leptin serum dibandingkan dengan perlakuan kontrol pada mencit yang diberi pakan yang mengandung fukosantin (Maeda et al., 2007).

f. Aktivitas penghambatan kolagenase

Kolagen membentuk 90\% dermis kulit. Kolagen didistribusikan ke seluruh dermis, membuat kulit cukup elastis dan kuat. Ketika kolagenase diaktifkan dan kolagen terdegradasi, fenomena penuaan seperti keriput dan kendur terjadi. Ekstrak Laminaria japanica (mengandung fukosantin 8,6\%) dapat menghambat aktivasi kolagenase, sehingga menyebabkan penghambatan degradasi kolagen (Peng et al., 2011).

g. Aktivitas penghambatan pigmentasi.

Pigmentasi terjadi karena adanya paparan sinar UV, sehingga terjadi penggelapan pada kulit. Semakin rendah nilai L (lightness) akan menunjukkan warna yang 
semakin gelap. Penambahan fukosantin $1 \%$ dapat menurunkan nilai L yang berarti kulit semakin terang. Dari hasil penelitian tersebut, fukosantin dapat menghambat pigmentasi dan mempercepat proses untuk menghilangkan deposit pigmen (Shimoda et al., 2010).

\section{PENUTUP}

Fukosantin merupakan karotenoid yang hanya dapat diperoleh dari alga coklat (makroalga), dan diatom (mikroalga). Kandungan fukosantin akan berbeda-beda tergantung dari jenis makroalga, umumnya kadarnya sangat kecil kurang dari $3 \mathrm{mg} / \mathrm{g}$ berat kering. Penelitian fukosantin lebih banyak dilakukan pada bioaktivitasnya yang bermanfaat untuk kesehatan, antara lain: antikanker, antiimflamasi, antidiabetes, antioksidan, antiobesitas, aktivitas penghambatan enzim kolagenase, dan aktivitas penghambatan pigmentasi. Uji bioaktivitas fukosantin sudah dilakukan baik pada hewan percobaan maupun manusia, namun demikian bagaimana proses detail mengenai alur kerja bioaktivitas fukosantin dalam tubuh masih membutuhkan penelitian yang lebih mendalam.

\section{DAFTAR PUSTAKA}

Afolayan, A. F., J. J. Bolton, C. A. Lategan, P. J. Smith, and D. R. Beukes. 2008. Fucoxanthin, tetraprenylated toluquinone and toluhydroquinone metabolites from Sargassum heterophyllum inhibit the in vitro growth of the malaria parasite Plasmodium falciparum. Z. Naturforsch. C. 63: 848-852.

Airanthi, M. W. A., M. Hosokawa, and K. Miyashita. 2011. Comparative antioxidant activity of edible Japanese brown seaweeds. $J$. Food Sci. 76: C104-C111.

Asai, A., T. Sugawara, H. Ono, and A. Nagao.2004. Biotransformation of fucoxanthinol into amarouciaxanthin $\mathrm{A}$ in mice and HepG2 cells: formation and cytotoxicity of fucoxanthin metabolites. Drug Metab. Dispos. 32: 205-211.

Ganesan, P., K. Noda, Y. Manabe, T. Ohkubo, Y. Tanaka, T. Maoka, T. Sugawara, and T. Hirata. 2011. Siphonaxanthin, a marine carotenoid from green algae, effectively induces apoptosis in human leukemia (HL-60) cells. Biochim. Biophys. Acta 1810: 497-503.

Heo, S.J., S. C. Ko, S. M. Kang, H. S. Kang, J. P. Kim, S. H. Kim, K. W. Lee, M. G. Cho, and J. Y. Jeon. 2008. Cytoprotective effect of fucoxanthin isolated from brown algae Sargassum siliquastrum against $\mathrm{H}_{2} \mathrm{O}_{2}$ induced cell damage. Eur. Food Res. Technol. 228: 145-151.

Heo, S. J., W. J. Yoon, K. N. Kim, G. N. Ahn, S. M. Kang, D. H. Kang, A. Affan, A.; C. Oh, W. K. Jung, 
and Y. J. Jeon. 2010. Evaluation of anti-inflammatory effect of fucoxanthin isolated from brown algae in lipopolysaccharide-stimulated RAW 264.7 macrophages. Food Chem. Toxicol. 48: 2045-2051.

Hosokawa, M., S. Wanezaki, K. Miyauchi, H. Kurihara, H. Kohno, J. Kawabata, J. Kawabata, S. Odashima, and K. Takahashi. 1999. Apoptosis-inducing effect of fucoxanthin on human leukemia cell line HL-60. Food Sci. Technol. Res. 5: 243-246.

Hosokawa, M., T. Miyashita, S. Nishikawa, S. Emi, T. Tsukui, F. Beppu, T. Okada, and K. Miyashita. 2010. Fucoxanthin regulates adipocytokine mRNA expression in white adipose tissue of diabetic/obese KK-Ay mice. Arch. Biochem. Biophys. 504: 17-25.

Jeon, S. M., H. J. Kim, M. N. Woo, M. K. Lee, Y. C. Shin, Y. B. Park, and M. S. Choi. 2010. Fucoxanthinrich seaweed extract suppresses body weight gain and improves lipid metabolism in high-fat-fed C57BL/6J mice. Biotechnol. J. 5: 961-969.

Kanazawa, K., Y. Ozaki, T. Hashimoto, S. K. Das, S. Matsushita, M. Hirano, T. Okada,, A. Komoto, N. Mori, and M. Nakatsuka. 2008 Commercial-scale preparation of biofunctional fucoxanthin from waste parts of brown sea algae Laminaria japonica. Food Sci. Technol. Res. 14: 573-582.

Kanda H., Y. Kamo, S. Machmudah, Wahyudiono and M. Goto. 2014. Extraction of fucoxanthin from raw macroalgae excluding drying and cell wall disruption by liquefied dimethyl ether. Mar. Drugs 12: 2383-2396, doi:10.3390/md12052383.

Kim, K.N., H. J. Heo, S. M. Kang, G. Ahn, G. and Y. J. Jeon. 2010a. Fucoxanthin induces apoptosis in human leukemia HL-60 cells through a ROS-mediated Bcl$\mathrm{xL}$ pathway. Toxicol. Vitro 24 : 1648-1654.

Kim, K. N., S. J. Heo,W. J. Yoon, S. M. Kang, G. Ahn,T. H. Yi, T.H. and Y. J. Jeon. 2010b. . Fucoxanthin inhibits the inflammatory response by suppressing the activation of NF- $\kappa \mathrm{B}$ and MAPKs in lipopolysaccharide-induced RAW 264.7 macrophages. Eur. J. Pharmacol. 649: 369-375.

Konishi, I, M. Hosokawa, T. Sashima, H. Kobayashi, and K. Miyashita. 2006. Halocynthiaxanthin and fucoxanthinol isolated from Halocynthia roretzi induce apoptosis in human leukemia, breast and colon cancer cells. Comp. Biochem. Phys. C. 142: 53-59. 
Kotake-Nara, E., M. Terasaki and A. Nagao. 2005. Characterization of apoptosis induced by fucoxanthin in human promyelocytic leukemia cells. Biosci. Biotechnol. Biochem. 69: 224-227.

Liu, C.L., Y. S. Huang, M. Hosokawa, K. Miyashita, and M. L. Hu. 2009. Inhibition of proliferation of a hepatoma cell line by fucoxanthin in relation to cell cycle arrest and enhanced gap junctional intercellular communication. Chem. Biol. Interact. 182: 165-172.

Maeda H., M. Hosokawa, T. Sashima, K. Funayama, and K. Miyashita. 2005. Fucoxanthin from edible seaweed, Undaria pinnatifida, shows antiobesity effect through UCP1 expression in white adipose tissues. Biochem. Biophys. Res. Commun. 332(2): 392-397.

Maeda H., M. Hosokawa, T. Sashima, and K. Miyashita. 2007. Dietary combination of fucoxanthin and fish oil attenuates the weight gain of white adipose tissue and decreases blood glucose in obese/diabetic KK-Ay mice. J. Agric. Food. Chem. 55(19): 7701-7706.

Mise, T., M. Ueda, and T. Yasumoto. 2011. Production of fucoxanthinrich powder from Cladosiphon okamuranus. Adv. J. Food Sci. Technol. 3: 73-76.
Miyashita, K., S. Nishikawa, F. Beppu, T. Tsukui, M. Abe, and M. Hosokawa. 2011. The allenic carotenoid fucoxanthin, a novel marine nutraceutical from brown seaweeds. J. Sci. Food Agric. 91: 1166-1174.

Miyata, M., T. Koyama, T. Kamitani, T. Toda, and K. Yazawa. 2009. Anti-obesity effect on rodents of the traditional Japanese food, tororokombu, shaved Laminaria. Biosci. Biotechnol. Biochem. 73: 2326-2328.

Murakami, C., M. Takemura, Y. Sugiyama, S. Kamisuki, H. Asahara, M. Kawasaki, T. Ishidoh, S. Linn, S. Yoshida, F. Sugawara, H. Yoshida, K. Sakaguchi, and Y. Mizushina. 2002. Vitamin A-related compounds, all-trans retinal and retinoic acids, selectively inhibit activities of mammalian replicative DNA polymerases. Biochim. Biophys. Acta 1574: 85-92.

Noviendri D., I. Jaswir, H. M. Salleh, M. Taher, K. Miyashita and N. Ramli. 2011. Fucoxanthin extraction and fatty acid analysis of Sargassum binderi and S. duplicatum. Journal of Medicinal Plants Research 5 (11): 2405-2412.

Park, H. J., M. K. Lee, Y. B. Park, Y. C. Shin, and M. S. Choi. 2011. Beneficial effects of Undaria pinnatifida ethanol extract on 
diet-induced-insulin resistance in C57BL/6J mice. Food Chem. Toxicol. 49: 727-733.

Peng J., J.P. Yuan, C. F. Wu and J. H. Wang. 2011. Fucoxanthin, a marine carotenoid present in brown seaweeds and diatoms: metabolism and bioactivities relevant to human health. Marine Drugs 9: 1806-1828, doi:10.3390/md9101806.

Ryabushko V. I., A. V. Prazukin, E. V. Popova and M. V. Nekhoroshev. 2014. Fucoxanthin of the brown alga Cystoseira barbata (Stackh.) C. Agardh from the Black Sea. J. Black Sea/ Mediterranean Environment 20 (2): 108-113.

Sachindra, N.M., E. Sato, H. Maeda, M. Hosokawa, Y. Niwano, M. Kohno, and K. Miyashita. 2007. Radical scavenging and singlet oxygen quenching activity of marine carotenoid fucoxanthin and its metabolites. J. Agric. Food Chem. 55: 8516-8522.

Sakai, S., T. Sugawara, and T. Hirata. 2011. Inhibitory effect of dietary carotenoids on dinitrofluorobenzene-induced contact hypersensitivity in mice. Biosci. Biotechnol. Biochem. 75: 1013-1015.

Sangeetha, R. K., N. Bhaskar, and V. Baskaran, V. 2008. Fucoxanthin restrains oxidative stress induced by retinol deficiency through modulation of $\mathrm{Na}^{+} \mathrm{K}^{+}$-
ATPase and antioxidant enzyme activities in rats. Eur. J. Nutr. 47: 432-441.

Sangeetha, R. K., N. Bhaskar, and V. Baskaran. 2009. Comparative effects of $\beta$-carotene and fucoxanthin on retinol deficiency induced oxidative stress in rats. Mol. Cell. Biochem. 331: 59-67.

Sangeetha, R. K., N. Bhaskar, S. Divakar, and V. Baskaran. 2010. Bioavailability and metabolism of fucoxanthin in rats: structural characterization of metabolites by LC-MS (APCI). Mol. Cell. Biochem. 333: 299-310.

Satomi, Y. and H. Nishino. 2007. Fucoxanthin, a natural carotenoid, induces G1 arrest and GADD45 gene expression in human cancer cells. Vivo, 21: 305-309.

Shimoda H., J. Tanaka, S. Shan, and T. Maoka. 2010. Antipigmentary activity of fucoxanthin and its influence on skin mRNA expression of melanogenic molecules. J. Pharmacy Pharmacol. 62:1137-1145.

Sudhakar M. P., J. S. Ananthalakshmi and B. N. Beena. 2013. Extraction, purification and study on antioxidant properties of fucoxanthin from brown seaweeds. Journal of Chemical and Pharmaceutical Research, 5 (7): 169-175. 
Woo, M. N., S. M. Jeon, H. J. Kim, M. K. Lee, S. K. Shin, Y. C. Shin, Y. B. Park, and M. S. Choi. 2010. Fucoxanthin supplementation improves plasma and hepatic lipid metabolism and blood glucose concentration in highfat fed C57BL/6N mice. Chem. Biol. Interact. 186: 316-322.

Yan, X., Y. Chuda, M. Suzuki, and T. Nagata. 1999. Fucoxanthin as the major antioxidant in Hijikia fusiformis, a common edible seaweed. Biosci. Biotechnol. Biochem. 63: 605-607.
Zailanie, K. and H. Purnomo. 2017. Identification of fucoxanthin from brown algae (Sargassum filipendula) from Padike village, Talango district, Sumenep regency, Madura islands, using nuclear magnetic resonance (NMR). International Food Research Journal, 24 (1): 372378.

Zaragoza, M. C., D. Lopez, M. P. Saiz, M. Poquet, J. Perez, P. PuigParellada, F. Marmol, P. Simonetti, C. Gardana, Y. Lerat, P. Burtin, C. Inisan, I. Rousseau, M. Besnard, and M. T. Mitjavila. 2008. Toxicity and antioxidant activity in vitro and in vivo of two Fucus vesiculosus extracts. J. Agric. Food Chem. 56: 7773-7780. 